\title{
Collagen type II modification by hypochlorite
}

\author{
Sławomir Olszowski ${ }^{2}$, Paweł $\mathrm{Mak}^{3}$, Ewa Olszowska ${ }^{2}$ and Janusz Marcinkiewicz ${ }^{1 凶}$ \\ ${ }^{1}$ Department of Immunology, Collegium Medicum, Jagiellonian University, Kraków, Poland; \\ ${ }^{2}$ Institute of Medical Chemistry, Collegium Medicum, Jagiellonian University, Kraków, Poland; \\ ${ }^{3}$ Faculty of Biotechnology, Jagiellonian University, Kraków, Poland
}

Received: 16 January, 2003; revised: 10 April, 2003; accepted: 20 April, 2003

Key words: collagen, hypochlorite, taurine chloramine, rheumatoid arthritis, oxidative modification

Oxidation of proteins is a common phenomenon in the inflammatory process mediated by highly reactive agents such as hypochlorite $\left(\mathrm{HOCl} / \mathrm{OCl}^{-}\right)$produced by activated neutrophils. For instance, in rheumatoid arthritis hypochlorite plays an important role in joint destruction. One of the major targets for $\mathrm{HOCl} / \mathrm{OCl}^{-}$is collagen type II (CII) - the primary cartilage protein. In our study, $\mathrm{HOCl} / \mathrm{OCl}^{-}$mediated collagen II modifications were tested using various methods: circular dichroism (CD), HPLC, ELISA, dynamic light scattering (DLS), fluorimetry and spectrophotometry. It was shown that hypochlorite action causes deamination with consecutive carbonyl group formation and transformation of tyrosine residues to dichlorotyrosine. Moreover, it was shown that ammonium chloramine $\left(\mathrm{NH}_{2} \mathrm{Cl}\right)$ formed in the reaction mixture reacts with CII. However, in this case the yield of carbonyl groups and dichlorotyrosine is lower than that observed for $\mathrm{HOCl} / \mathrm{OCl}^{-}$by $50 \%$. CD data revealed that collagen II exists as a random coil in the samples and that chlorination is followed by CII fragmentation. In the range of low $\mathrm{HOCl} / \mathrm{OCl}^{-}$concentrations (up to $1 \mathrm{mM}$ ) $10-90 \mathrm{kDa}$ peptides are predominant whereas massive production of shorter peptides was observed for high (5 mM) hypochlorite concentration. DLS measurements showed that chlorination with $\mathrm{HOCl} / \mathrm{OCl}^{-}$decreases the radius of collagen II aggregates from 30 to $6.8 \mathrm{~nm}$. Taking into account the fact that chlorinated collagen is partially degraded, the DLS results suggest that smaller micelles are formed of the 10-90 kDa peptide fraction. Moreover, collagen chlorination results in epitope modification which affects CII recognition by anti-CII antibodies. Finally, since in the synovial fluid the plausible hypochlorite concentration is smaller than that used in the model the change of size of molecular aggregates seems to be the best marker of hypochlorite-mediated collagen oxidation.

\footnotetext{
${ }_{\text {This work was supported by a grant from the State Committee for Scientific Research (KBN, Poland) }}$ grant No. 4P05B01018.

${ }^{凶}$ Corresponding author: Department of Immunology, Collegium Medicum, Jagiellonian University, 31-121 Kraków, Czysta 18, Poland; fax: (48 12) 633 9431; e-mail: mmmarcin@cyf-kr.edu.pl

Abbreviations: BSA, bovine serum albumin; CII, collagen type II; HRP, horseradish peroxidase; OPD, $o$-phenylenediamine dihydrochloride; PMNs, neutrophils; RA, rheumatoid arthritis; ROS, reactive oxygen species; TFA, trifluoroacetic acid.
} 
Protein oxidation by reactive oxygen species (ROS) plays an important role in the pathomechanism of inflammatory diseases. ROS are produced by neutrophils, the main cells of inflammed synovial fluid in rheumatoid arthritis (RA). They are responsible for cartilage damage and joint erosion observed in this disease. The most toxic ROS generated by activated neutrophils is hypochlorite ( $\mathrm{HOCl} /$ $\mathrm{OCl}^{-}$) - the product of the myeloperoxidase $/ \mathrm{Cl}^{-} /$hydrogen peroxide system (Weiss et al., 1982). Collagen type II (CII) is a primary protein component of cartilage and destruction of this protein caused by hypochlorite and by collagenase is one of the principal pathological reactions observed in RA (Edwards \& Hallett, 1997).

It has been demonstrated (Weiss et al., 1983) that $\mathrm{HOCl} / \mathrm{OCl}^{-}$can react rapidly with amino acids and proteins to form low molecular and protein $N$-mono(di)chloramines. Davies et al. (1993) have shown that hypochlorite action leads to intensive fragmentation of tritiated acid soluble bovine collagen type II and that some of the amino acid-derived chloramines ( $N$-chloroleucine or $N$-chloroalanine) increase the proteolytic susceptibility of $N$-chloramine modified collagen. At present, however, the knowledge of the early stages of $\mathrm{HOCl} / \mathrm{OCl}^{-}$ mediated collagen oxidation is poor. In our study we used various methods to monitor hypochlorite-mediated changes in CII aminoacid residues as well as changes in the structure of this protein.

\section{MATERIALS AND METHODS}

Chemicals. Collagen type II (CII) from chicken sternal cartilage, pronase E, biotinylated goat anti-mouse IgG antibody, potassium hydroxide, acetonitrile, sulfuric acid, hydrochloric acid, citric acid, sodium mono- and dihydrophosphate, ammonium dihydrophosphate, guanidinium hydrochloride, sodium thiosulfate, hydrogen peroxide, o-phenylenediamine dihydrochloride, 2,4,6-trinitro- benzenesulfonic acid, ethanol and ethyl acetate were obtained from Sigma (St. Louis, U.S.A.). 2,4-Dinitrophenylhydrazine was from Merck (Darmstadt, Germany). Sodium hypochlorite $(\mathrm{NaOCl})$ and sodium chloride were from Aldrich Chemie (Steinheim, Germany). Taurine, Nessler reagent and trifluoroacetic acid (TFA) were from Fluka Chemica AG (Buchs, Switzerland). Anti-human collagen type II antibody monoclonal purified IgG (clone II 4011) was from ICN Biomedicals, Inc. (U.S.A.). Horseradish peroxidase streptavidin was from Vector Lab (Burlingame, CA, U.S.A.). $\mathrm{NaOCl}$ solutions were prepared prior to use from $0.57 \mathrm{M}$ stock solution and standardized iodometrically (Stelmaszyńska \& Zgliczyński, 1978).

Ammonium monochloramine synthesis. Two millimolar $\mathrm{NH}_{2} \mathrm{Cl}$ was prepared prior to use in a cuvette. Forty microliters of $4 \mathrm{mM}$ $\mathrm{HOCl} / \mathrm{OCl}^{-}$in $0.2 \mathrm{M}$ phosphate buffer, $\mathrm{pH}$ 7.4, was added to $0.96 \mathrm{ml}$ of $4 \mathrm{mM} \mathrm{NH}_{4} \mathrm{H}_{2} \mathrm{PO}_{4}$ in the same buffer.

Taurine monochloramine synthesis. Taurine monochloramine solutions (1-5 mM) were prepared as follows. One millilitre of 2-10 mM hypochlorite solution in $0.2 \mathrm{M}$ phosphate buffer, $\mathrm{pH}$ 7.4, was added dropwise to 1 $\mathrm{ml}$ of 2-10 $\mathrm{mM}$ taurine in the same buffer. The final taurine monochloramine concentration was calculated using $\varepsilon_{253 \mathrm{~nm}}=0.4 \mathrm{mM}^{-1}$ $\times \mathrm{cm}^{-1}$ (Stelmaszyńska \& Zgliczyński, 1978).

Collagen chlorination with $\mathrm{HOCl} / \mathrm{OCl}^{-}$ (1), ammonium monochloramine (2) or taurine monochloramine (3). (1) Samples of collagen $(2 \mathrm{mg} / \mathrm{ml})$ in $0.2 \mathrm{M}$ phosphate buffer, $\mathrm{pH} 7.4$, with $0.2 \mathrm{M} \mathrm{NaCl}$ were incubated for $2 \mathrm{~h}$ with 1,3 or $5 \mathrm{mM} \mathrm{HOCl} / \mathrm{OCl}^{-}$or for $30 \mathrm{~min}$ with $0.2,1,2$ or $4 \mathrm{mM} \mathrm{HOCl} / \mathrm{OCl}^{-}$. To stop the reaction the samples were treated with a steichiometric amount of thiosulfate (1/1). The dichlorotyrosine, tyrosine and aldehyde groups were assayed in the samples and additionally in the fractions of molecular mass $<10 \mathrm{kDa}$.

(2 and 3). Collagen samples ( $1 \mathrm{mg} / \mathrm{ml}$ ) in 0.2 $\mathrm{M}$ phosphate buffer, $\mathrm{pH}$ 7.4, with $0.2 \mathrm{M} \mathrm{NaCl}$ 
were incubated with $2 \mathrm{mM}$ ammonium chloramine or with 1,3 or $5 \mathrm{mM}$ taurine chloramine for $2 \mathrm{~h}$ at $37^{\circ} \mathrm{C}$. The progress of reaction (2) was monitored by the decrease of absorption at $253 \mathrm{~nm}$ and the resulting $\mathrm{NH}_{2} \mathrm{Cl}$ concentrations were calculated as above.

Estimation of dichlorotyrosine. Dichlorotyrosine concentration was calculated from difference spectra of chlorinated collagen (2 $\mathrm{mg} / \mathrm{ml}$ ) using $\varepsilon_{306 \mathrm{~nm}}=4.7 \mathrm{mM}^{-1} \times \mathrm{cm}^{-1}$ (Rudie et al., 1980). The reference cuvette contained native collagen solution $(2 \mathrm{mg} / \mathrm{ml})$. To reduce turbidity the samples were incubated with a $10 \mu \mathrm{g} / \mathrm{ml}$ solution of pronase $\mathrm{E}$ for 30 min prior to measurements.

Estimation of tyrosine and bityrosine. The fraction (\%) of intact tyrosine moieties in collagen samples $(2 \mathrm{mg} / \mathrm{ml})$ was calculated from the relative fluorescence intensity (RFI) for emission at 307-309 $\mathrm{nm}$ (excitation at 275 $\mathrm{nm})$. Bityrosine fluorescence was excited at $310 \mathrm{~nm}$ and monitored for emission at 410 $\mathrm{nm}$.

Assay of carbonyl groups. Carbonyl groups were determined as dinitrophenylhydrazones according to Oliver (1987). Assays were carried out in $0.1 \mathrm{ml}$ samples of native and chlorinated collagen $(0.2 \mathrm{mg})$ and the concentration of protein dinitrophenylhydrazones was calculated using absorption coefficient $\varepsilon_{368 \mathrm{~nm}}=21 \mathrm{mM}^{-1} \times \mathrm{cm}^{-1}$.

Assay of ammonium. Ammonium, a HOCl-mediated deamination product, was assayed using Nessler reagent. Fifty microliters of collagen $(0.1 \mathrm{mg})$ sample was added to the assay buffer containing Nessler stock solution diluted with $0.12 \mathrm{M} \mathrm{KOH} \mathrm{(1:4,} \mathrm{v/v).} \mathrm{Absorp-}$ tion at $430 \mathrm{~nm}$ was measured after $30 \mathrm{~min}$ incubation at $37^{\circ} \mathrm{C}$ and ammonium concentration was evaluated from a standard curve obtained for 5-100 $\mu \mathrm{M} \mathrm{NH}_{4} \mathrm{H}_{2} \mathrm{PO}_{4}$ solutions.

HPLC assays. (1) Assays were performed using an apparatus (Waters Millipore Comp., U.S.A.) equipped with a $\mu$ Bondpack C-18 column $(3.9 \times 300 \mathrm{~nm})$ and the buffer set as follows: (A) $0.1 \%$ TFA in water, (B) $0.07 \%$ TFA in $80 \%$ acetonitrile in water. Gradient was formed from 0 to $100 \%$ of $\mathrm{B}$ within $15 \mathrm{~min}$. Twenty micrograms of unchlorinated or HOCl-modified collagen was loaded onto the column. (2) Assays were performed using a Shimadzu SCL 10A apparatus equipped with a Supelcosil ${ }^{\text {TM }}$ LC-318 C-18 column $(4 \times 250$ $\mathrm{mm}$ ) and the buffer set as follows: (A) $0.1 \%$ TFA in water, (B) $0.1 \%$ TFA in acetonitrile. Gradient was formed from 0 to $100 \%$ of B within $30 \mathrm{~min}$. One hundred microliters of sample was filtered through a Milipore YM 10 $\mathrm{kDa}$ membrane and loaded on to the column.

Electrophoresis. SDS/PAGE was performed in a MiniProtean II apparatus (BioRad, U.S.A.) using Tris/Tricine protein gels, $3.25 \mu \mathrm{g}$ of total protein was loaded into each well. The gels were stained with Coomassie Blue R-250 or silver stained.

Competitive ELISA. To determine collagen epitope modification by chlorination competitive ELISA was used. Briefly, microtiter plates (Corning, U.S.A.) were coated with 5 $\mu \mathrm{g} / \mathrm{ml}$ of CII. The antigens tested (CII modified by $\mathrm{HOCl} / \mathrm{OCl}^{-}$or taurine monochloramine) at $0.5-50 \mu \mathrm{g} / \mathrm{ml}$ were mixed with an anti-CII monoclonal antibody $(12.5 \mu \mathrm{g})$ and then added and incubated with a fixed competitive antigen for $1 \mathrm{~h}$ at room temperature and washed $3 \times$ to remove nonadsorbed immune complexes. The plates were then incubated with biotinylated goat anti-mouse antibody for $45 \mathrm{~min}$ at room temperature. Horseradish peroxidase (HRP) conjugated streptavidin diluted 1:1000 in 1\% BSA/PBS was added and the plates were incubated for $45 \mathrm{~min}$ at room temperature. Then o-phenylenediamine dihydrochloride (OPD) was used as a substrate (5 $\mathrm{mg}$ of OPD in $10 \mathrm{ml}$ of phosphate/citrate buffer $\mathrm{pH}$ 5.0) and incubated with $40 \mu \mathrm{l}$ of $30 \% \mathrm{H}_{2} \mathrm{O}_{2}$ for $30 \mathrm{~min}$ at room temperature. The reaction was stopped with $3 \mathrm{M} \mathrm{H}_{2} \mathrm{SO}_{4}$. Absorbance was measured at $492 \mathrm{~nm}$. As a control we used AgAb complex formation without preincubation with free test antigen $\left(\mathrm{A}_{490}=1.25\right)$.

Spectrophotometric measurements were carried out with a U-2000 spectrophotometer 
(Hitachi, Japan) and fluorescence spectra were recorded with an F-2000 fluorescence spectrophotometer (Hitachi, Japan). Circular dichroism spectra (CD) of $2.2 \mu \mathrm{M}$ collagen solutions were measured with a J710 spectropolarimeter (Jasco, Japan).

Dynamic light scattering measurements were performed with an MS200 (831.6 nm) laser unit (DynaPro, England) for collagen solutions of $1.5 \mathrm{mg} / \mathrm{ml}$ in $0.2 \mathrm{M}$ phosphate buffer ily traced as absorbance increase at 305-308 $\mathrm{nm}$ in the difference spectra of chlorinated CII. Since CII does not contain tryptophan moieties it was possible to record the weak tyrosine fluorescence at $305 \mathrm{~nm}$. This emission diminished with increasing $\mathrm{HOCl} / \mathrm{OCl}^{-}$concentration and could be treated as a measure of the content of intact tyrosine moieties in CII (Table 1). The dichlorotyrosine formation in CII was dose dependent and correlated with

Table 1. $\mathrm{HOCl} / \mathrm{OCl}^{-}$mediated amino-acid side chain modification and its influence on CII aggregate formation

\begin{tabular}{lllll}
\hline \multirow{2}{*}{ Content } & \multicolumn{3}{l}{ Unchlorinated CII } & \multicolumn{3}{l}{ CII chlorinated } & with HOCl/OCl & \\
\cline { 2 - 5 } & & $1 \mathrm{mM}$ & $3 \mathrm{mM}$ & $5 \mathrm{mM}$ \\
\hline Dichlorotyrosine $(\mu \mathrm{M})$ & 0 & 26 & 34 & 47 \\
Tyrosine (\%) & 100 & 46.7 & 23.2 & 12.0 \\
Carbonyl $(\mu \mathrm{M})$ & 5.7 & 11.9 & 24.13 & 44.7 \\
Ammonium $(\mu \mathrm{M})$ & 0.0 & 614.0 & 45.0 & 0.0 \\
Radius (nm)* & 30 & 9.2 & 8.5 & 6.8 \\
\hline
\end{tabular}

Data represent averages of three measurements and refer to $22 \mu \mathrm{M}$ CII concentration (calculated for $90 \mathrm{kDa}$ CII species). *The evaluated radii represent the most abundant fraction (70-90\%) of total content. Artificial radii over $100 \mathrm{~nm}$ were out of measurement range. All samples showed an additional artificial radius of $0.2 \mathrm{~nm}$ in the assay buffer control.

with $0.2 \mathrm{M} \mathrm{NaCl}$. Samples of collagen unchlorinated and chlorinated with 1,3 or $5 \mathrm{mM}$ $\mathrm{HOCl}$ were filtered $(100 \mathrm{~nm})$ prior to the measurements. Radii (nm) were evaluated on the assumption that collagen exists in solution as a randomly coiled structure. Calculations were performed using an updated version of Dynamics Software (DynaPro, England).

\section{RESULTS}

It is widely known that protein chlorination results in modification of reactive amino-acid side chains containing such functional groups as: -SH, -SS-, RSR, $-\mathrm{NH}_{2}, \mathrm{OH}$ (in Tyr) or indole (in Trp) (Hampton et al., 1998). Chlorination of collagen II with $\mathrm{HOCl} / \mathrm{OCl}^{-}$leads to the conversion of tyrosine to dichlorotyrosine as it was observed for other proteins (Kettle, 1996; Olszowski et al., 1996). As shown in Table 1 dichlorotyrosine formation could be eas- the loss of tyrosine moieties in the samples. Moreover, a shorter chlorination time (30 $\mathrm{min})$ at the same range of $\mathrm{HOCl} / \mathrm{OCl}^{-}$concentrations (0.1-4 mM) produced a similar content (up to $40 \mu \mathrm{M}$ ) of dichlorotyrosine in 22 $\mu \mathrm{M}$ collagen (not shown). On the other hand, the $5 \mathrm{mM}$ taurine monochloramine-mediated collagen chlorination did not lead to dichlorotyrosine formation although the more reactive $5 \mathrm{mM} \mathrm{NH}_{2} \mathrm{Cl}$ did produce dichlorotyrosine. The yield of the latter process was, however, lower (50\%) than that of corresponding $5 \mathrm{mM} \mathrm{HOCl} / \mathrm{OCl}^{-}$solution (not shown).

Additionally bityrosine formation was detected in CII samples treated with $5 \mathrm{mM}$ $\mathrm{HOCl} / \mathrm{OCl}^{-}$. However, the bityrosine fluorescence at $410 \mathrm{~nm}$ was too weak to permit evaluation of its concentration. Since CII does not contain other (e.g. tryptophan) moieties which could serve as markers of oxidation, the dichlorotyrosine content seems to correlate with the degree of CII modification. 
The $\mathrm{HOCl} / \mathrm{OCl}^{-}$mediated chlorination of lysine $\varepsilon$-amino groups in collagen converted them to aldehydes with concomitant deamination. Ammonium evolved in the reaction mixture was quickly converted with an excess of $\mathrm{HOCl}$ to mono- and dichloramines which in turn could chlorinate the protein. Ammonium chloramine-mediated CII chlorination was confirmed spectrophotometrically. Our results suggest that up to $15 \%$ of the initial amount of ammonium monochloramine reacted with CII during a $2 \mathrm{~h}$ incubation $(27 \mathrm{am}$ monium monochloramines/collagen, mol/ mol). Ammonium and carbonyl group contents in $\mathrm{HOCl} / \mathrm{OCl}^{-}$treated $\mathrm{CII}$ are shown in Table 1. Whereas the carbonyl group content gradually increased with $\mathrm{HOCl} / \mathrm{OCl}^{-}$concentration to reach $45 \mu \mathrm{M}$ (approx. 2 carbonyl groups for a $90 \mathrm{kDa}$ fragment), the ammonium concentration was the highest for relatively low $(1 \mathrm{mM}) \mathrm{HOCl} / \mathrm{OCl}^{-}$concentration (Table 1). The latter result suggests that intensive deamination prevails up to $1 \mathrm{mM}$ hypochlorite concentration, whereas at higher $\mathrm{HOCl} / \mathrm{OCl}^{-}$concentration the deamination is followed by the reaction that transforms the ammonium produced to chloramines $\left(\mathrm{NH}_{2} \mathrm{Cl}\right.$ and $\mathrm{NHCl}_{2}$ ).

Circular dichroism spectra (CD) revealed changes in the content of secondary structures in CII samples. As shown in Fig. 1, an increase of the $\mathrm{HOCl} / \mathrm{OCl}^{-}$concentration decreased the ellipticity in the range of 190-240 $\mathrm{nm}(\mathrm{n}-\pi *)$. All spectra correspond to random coil structure and suggest an absence of triple helix in all samples. Thus, the lower $\theta$ corresponds to a higher content of degraded uncoiled $\alpha$ (II) collagen chains. Since the spectra showed the same position ( $220 \mathrm{~nm}$ ) of $\theta$ maximum it could be concluded that no other secondary collagen structures formed during chlorination. These results correlate with the concomitant decrease of the content of high molecular CII fraction - calculated from the peak height for 10.9 min retention time (Table 2). In addition, the presence of low molecular mass peptides in collagen samples filtered through a $10 \mathrm{kDa}$ membrane was confirmed. The HPLC profiles shown in Fig. 2 suggest that only the highest $\mathrm{HOCl} / \mathrm{OCl}^{-}$concentration let to a massive formation of low molecular mass $(<10 \mathrm{kDa})$ peptides.

The antigen-antibody reaction between chlorinated collagen and a monoclonal antibody specific to native collagen was used to determine epitope deterioration caused by $\mathrm{HOCl} / \mathrm{OCl}^{-}$and taurine monochloramine. $\mathrm{HOCl} / \mathrm{OCl}^{-}$in a dose dependent manner affected the formation of immune complexes as shown in Fig. 3. This indicates that $\mathrm{HOCl} / \mathrm{OCl}^{-}$, used at concentrations higher than $1 \mathrm{mM}$, seriously changed the epitope structure of CII, which did not compete with native CII for the specific antibody. In contrast to $\mathrm{HOCl} / \mathrm{OCl}^{-}$, taurine monochloramine did not affect the ability of collagen to react

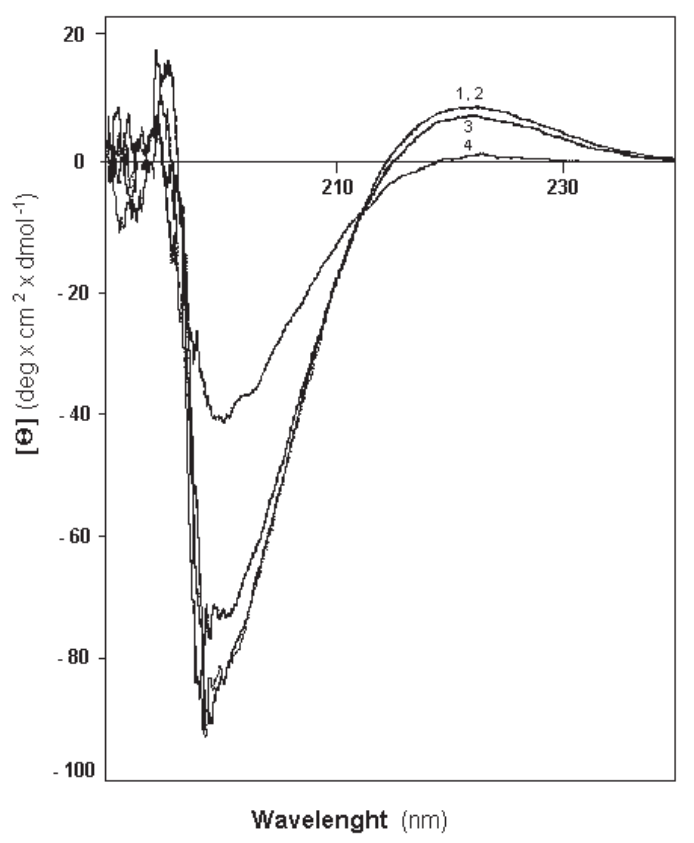

Figure 1. CD spectra of unchlorinated CII (1) and CII chlorinated with $0.2 \mathrm{mM}(2), 1.0 \mathrm{mM}$ (3) and 4 mM (4) $\mathrm{HOCl} / \mathrm{OCl}^{-}$.

Samples contained 2.2 $\mu \mathrm{M}$ CII in $0.2 \mathrm{M}$ phosphate buffer with $0.2 \mathrm{M} \mathrm{NaCl}, \mathrm{pH} 7.4$.

with the antibody specific for the native protein (Fig. 4).

SDS profiles (data not shown) indicated that the molar mass of unchlorinated CII was 
Table 2. Influence of $\mathrm{HOCl} / \mathrm{OCl}^{-}$on $\mathrm{CII}$ structure

\begin{tabular}{|c|c|c|c|c|}
\hline \multirow[t]{2}{*}{ Content } & \multirow[t]{2}{*}{ Unchlorinated CII } & \multicolumn{3}{|c|}{ CII chlorinated with $\mathrm{HOCl} / \mathrm{OCl}^{-}$} \\
\hline & & $0.2 \mathrm{mM}$ & $1 \mathrm{mM}$ & $4 \mathrm{mM}$ \\
\hline Secondary structure (\%)* & 100 & 96.1 & 82.2 & 16.4 \\
\hline Peptide bonds $(\%)^{* *}$ & 100 & 78.6 & 32.5 & 17.5 \\
\hline
\end{tabular}

${ }^{*} \mathrm{CD}$ data for $2.2 \mu \mathrm{M}$ CII; **HPLC data derived from CII peak height (10.9 min retention time). For other details see Methods - HPLC procedure (1).

90-95 kDa and that the $\mathrm{HOCl} / \mathrm{OCl}^{-}$-mediated fragmentation of CII could be monitored even
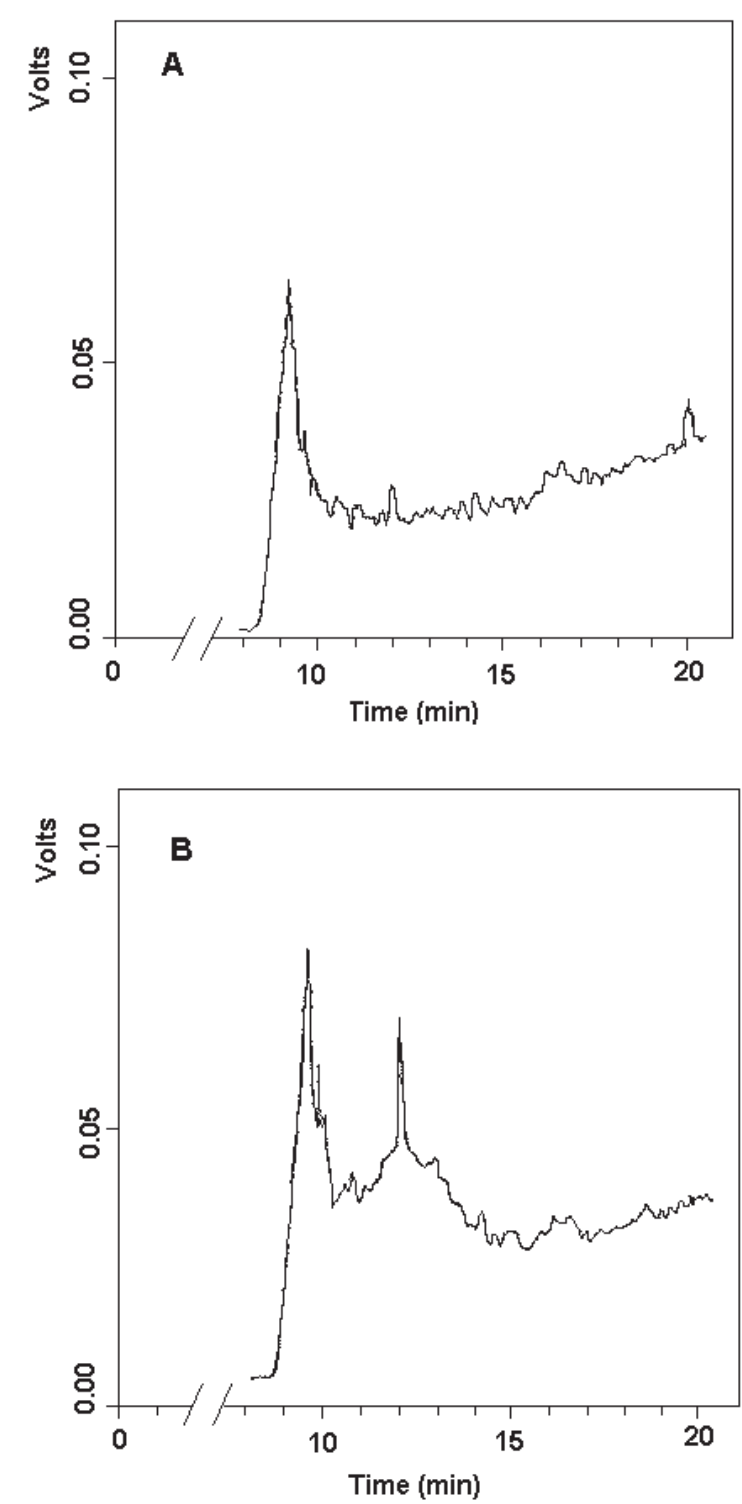

Figure 2. HPLC profiles of CII derived peptide $(<$ $10 \mathrm{kDa}$ ) fraction of unchlorinated CII (A) and CII chlorinated with $5 \mathrm{mM} \mathrm{HOCl} / \mathrm{OCl}^{-}$(B).

Fractions of CII chlorinated with 1 and $3 \mathrm{mM} \mathrm{HOCl} /$ $\mathrm{OCl}^{-}$showed the same profile as profile A. within low $\mathrm{HOCl} / \mathrm{OCl}^{-}$concentration range (up to $1 \mathrm{mM}$ ). Samples of chlorinated CII gave one main band whose thickness diminished proportionally to the chlorination level both on Commassie and silver stained gels. Although no additional low molecular bands were found, dichlorotyrosine and carbonyls were detected in fractions (molecular mass

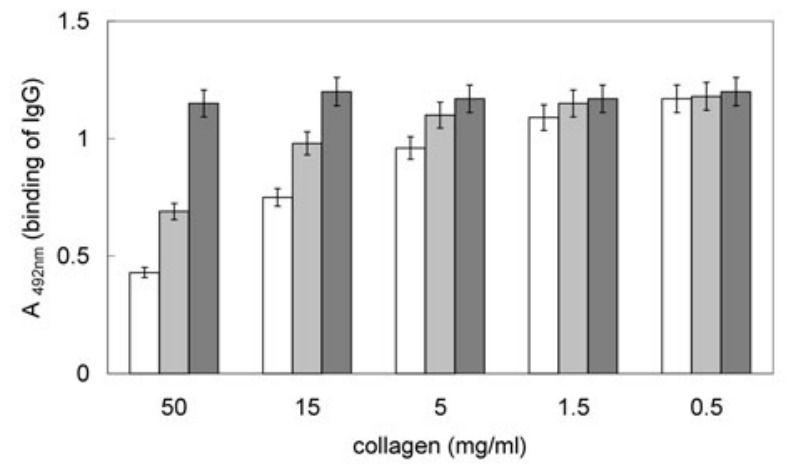

Figure 3. Effect of $\mathrm{HOCl} / \mathrm{OCl}^{-}$modification on immune complex formation.

Competitive ELISA was used. Bars represent: unchlorinated CII ( $\square$ ) and CII chlorinated with $1(\square)$ or 3 (ロ) $\mathrm{mM} \mathrm{HOCl} / \mathrm{OCl}^{-}$. The results represent three independent experiments and are expressed as mean \pm S.E.M.

$<10 \mathrm{kDa}$ ) derived from CII samples chlorinated with 3 and $5 \mathrm{mM} \mathrm{HOCl} / \mathrm{OCl}^{-}$(not shown). The latter result suggests the presence of low molecular mass oxidatively modified peptides in the samples.

The dynamic light scattering method (DLS) was used to monitor changes in CII aggregates in water. The DLS data shown in Table 1 suggest that $\mathrm{HOCl} / \mathrm{OCl}^{-}$chlorination decreased the radius of existing CII structures. Unchlorinated CII micelles had the radius of 
$30 \mathrm{~nm}$ which corresponds to a structure of molecular mass 900-9000 kDa, much higher (10-100 times) than the mass of a single collagen molecule $(90 \mathrm{kDa})$. Although the calcu-

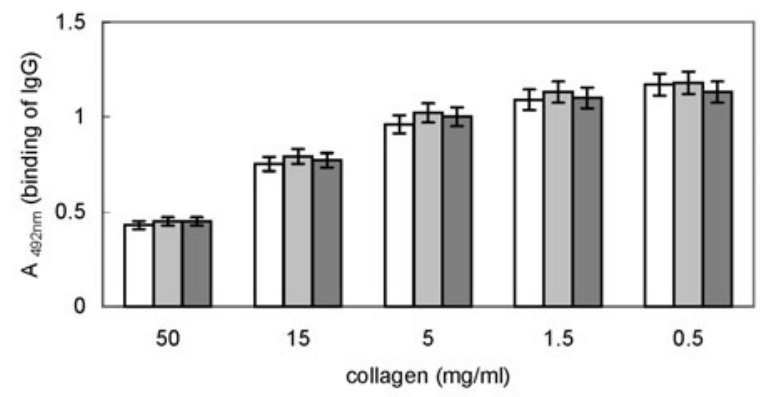

Figure 4. Effect of taurine monochloramine modification on immune complex formation.

Bars represent unchlorinated CII ( $\square$ ) and CII chlorinated with $1(\square)$ or $3(\square) \mathrm{mM}$ taurine monochloramine. Other details as for Fig. 3.

lated mass depends strongly on the assumptions made (globular proteins or pollulans) the hypochlorite mediated relative decrease of the radius is unquestionable. Samples containing chlorinated collagen showed a radius corresponding to the molecular mass 150$200 \mathrm{kDa}$.

\section{DISCUSSION}

In this study we tested the ability of $\mathrm{HOCl} /$ $\mathrm{OCl}^{-}$, a product of activated neutrophils, to modify the structure of collagen type II - the major protein present in joint cartilage. The present data suggest that hypochlorite modifies amino-acid side chains, secondary structure and type of aggregate. Assuming the molecular mass of CII to be approx. $90 \mathrm{kDa}$ one could estimate the dichlorotyrosine and aldehyde content per one collagen molecule. The numbers of dichlorotyrosine moieties as well as of aldehyde groups vary from 0.25 to 2 per collagen molecule in collagen II samples modified with $1-5 \mathrm{mM} \mathrm{HOCl} / \mathrm{OCl}^{-}$. Unlike the stable dichlorotyrosine moieties, aldehydes are easily oxidized with an excess of $\mathrm{HOCl} / \mathrm{OCl}^{-}$. Therefore, due to further oxidation, carbonyl groups were not detected in collagen samples chlorinated with more concentrated HOCl/ $\mathrm{OCl}^{-}(>5 \mathrm{mM})$.

At low hypochlorite concentrations (up to $1 \mathrm{mM}$ ) ammonium content seems to be a better marker of lysine group oxidation since carbonyl formation is concomitant with deamination. These results are also supported by the fact that free amino group level in CII samples was not elevated as shown by the 2,4,6-trinitrobenzenesulfonic method (not shown) and are consistent with the suggestion that $\mathrm{HOCl} / \mathrm{OCl}^{-}$-modified amino groups are unavailable for reaction with fluorescamine (Davies et al., 1987). At higher $\mathrm{HOCl} / \mathrm{OCl}^{-}$ concentrations ( 3 and $5 \mathrm{mM}$ ) ammonium level was decreased which could be interpreted in terms of the ammonium chloramine formation in the presence of $\mathrm{HOCl} / \mathrm{OCl}^{-}$(Table 1). All these facts taken together suggest that collagen is chlorinated with both $\mathrm{HOCl} / \mathrm{OCl}^{-}$and ammonium chloramine and that the higher the initial $\mathrm{HOCl} / \mathrm{OCl}^{-}$concentration, the higher the ammonium monochloramine content in the reaction mixture.

As suggested by the HPLC, SDS/PAGE and CD data, hypochlorite chlorination was followed by CII fragmentation even at low hypochlorite concentrations (less than $1 \mathrm{mM}$ ). Unlike in the case of albumin (Olszowski et al., 1996) and fibronectin (Vissers \& Winterbourn, 1991), for collagen this tendency seems to prevail over aggregation. The degree of CII fragmentation evaluated from CD measurements was very similar to that calculated from experiments with tritium labelled type II bovine articular collagen (Davies et al., 1993). The data from competitive ELISA showed that $\mathrm{HOCl} / \mathrm{OCl}^{-}$at low concentrations (up to $1 \mathrm{mM}$ ) did not affect the formation of immune complexes between chlorinated CII and anti-collagen specific antibodies. This may suggest that the structure of the epitopes was not affected. Nevertheless, lysine and tyrosine modifications in CII molecules were observed. On the other hand, $\mathrm{HOCl} / \mathrm{OCl}^{-}$at higher concentrations ( $35 \mathrm{mM}$ ) significantly diminished 
the binding of the antibody due to the fragmentation of CII. In contrast to $\mathrm{HOCl} / \mathrm{OCl}^{-}$, taurine monochloramine did not affect CII binding to the antibody. Therefore, these results suggest that taurine may prevent collagen structure deterioration in vivo, since taurine monochloramine is formed from hypochlorite at the inflammation site (Weiss et al., 1982).

Our results demonstrating that chlorination was followed by fragmentation, it leads to the conclusion that the structures found in chlorinated CII samples (DLS) are aggregates of chlorinated low molecular CII-derived peptides. However, since physiological hypochlorite or chloramine concentrations are lower $(\mu \mathrm{M})$ than those used in our model system, only slight $(<10 \%)$ collagen degradation could be expected in the synovial fluid. Thus it could be suggested that in the inflammatory process the radius of CII micelles decreases approx. 3-5 times. The components of these modified micelles are probably weakly bound peptides (10-90 kDa) containing carbonyl groups and exhibiting more anionic character than intact collagen (Olszowski et al., 1996). The dramatic change in the size and composition of CII aggregates may influence the properties of the synovial fluid. At present, the biological role of this process is unknown, although, as it has been observed for fibronectin (Olszowski et al., 1994), it is possible that this modification may influence PMN activation in the synovial fluid.

Finally, our data confirm previous observations that chlorination of a protein by $\mathrm{HOCl} / \mathrm{OCl}^{-}$may alter its properties, including structure, susceptibility to proteolysis, immunogenity and pathogenecity (Marcinkiewicz et al., 1991; 1992; Kwaśny-Krochin et al., 2002). However, the effect of $\mathrm{HOCl} / \mathrm{OCl}^{-}$on the protein properties will be different, depending on the exposure of target amino acids in the chlorinated protein (e.g., ovalbumin vs. collagen).

\section{R E F E R E N C E S}

Davies KJA, Delsignore ME, Lin SW. (1987) Protein damage and degradation by oxygen radicals II. Primary structure. J Biol Chem.; 262: 9902-7.

Davies JMS, Horwittz DA, Davies KJL. (1993) Potential roles of hypochlorous acid and $N$-chloramines in collagen breakdown by phagocytic cells in synovitis. Free Radic Biol Med.; 15: 637-43.

Edwards SW, Hallett MB. (1997) Seeing the wood for the trees: the forgotten role of neutrophils in rheumatoid arthritis. Immunol Today.; 18: $320-4$.

Hampton MB, Kettle AJ, Winterbourn CC. (1998) Inside the neutrophil phagosome: oxidants, myeloperoxidase and bacterial killing. Blood.; 92: 3007-17.

Kettle AJ. (1996) Neutrophils convert tyrosyl residues in albumin to chlorotyrosine. FEBS Lett.; 379: 103-6.

Kwaśny-Krochin B, Bobek M, Kontny E, Gluszko P, Biedroń R, Chain BM, Maśliński W, Marcinkiewicz J. (2002) Effect of taurine chloramine. The product of activated neutrophils, on the development of collagen-induced arthritis in DBA 1/J mice. Amino Acids.; 23: 419-26.

Marcinkiewicz J, Chain BM, Olszowska E, Olszowski S, Zgliczyński JM. (1991) Enhancement of immunogenic properties of ovalbumin as a result of its chlorination. Int $J$ Biochem.; 23: $1393-5$.

Marcinkiewicz J, Olszowska E, Olszowski S, Zgliczyński JM. (1992) Enhancement of trinitrophenyl - specific humoral response to TNP proteins as a result of carrier chlorination. Immunology.; 76: 385-8.

Oliver CN. (1987) Inactivation of enzymes and oxidative modification of proteins by stimulated neutrophils. Arch Biochem Biophys.; 253: $62-72$.

Olszowski S, Olszowska E, Stelmaszyńska T, Kursa A. (1994) Influence of native and oxidized proteins on tumour necrosis factor preactivated PMN leukocytes. Anal Chim Acta.; 290: 186-9. 
Olszowski S, Olszowska E, Stelmaszyńska T, Krawczyk A, Marcinkiewicz J, Baczek N. (1996) Oxidative modification of albumin. Acta Biochim Polon.; 43: 661-72.

Rudie NG, Porter DJT, Bright HJ. (1980) Chlorination of an active site tyrosyl residue in D-amino-acid oxidase by $N$-chloro-D-leucine. $J$ Biol Chem.; 255: 498-508.

Stelmaszyńska T, Zgliczyński JM. (1978) $N$-(2Oxoacyl)-amino acids and nitryles as final products of dipeptyde chlorination mediated by the myeloperoxidase- $\mathrm{H}_{2} \mathrm{O}_{2} \mathrm{Cl}^{-}$system. Eur J Biochem.; 92: 301-8.
Vissers MCM, Winterbourn CC. (1991) Oxidative damage to fibronectin. I. The effects of the myeloperoxidase system and $\mathrm{HOCl}$. Arch Biochem Biophys.; 285: 53-9.

Weiss SJ, Slivka A, Wei M. (1982) Chlorination of taurine by human neutrophils. Evidence for hypochlorous acid generation. J Clin Invest.; 70: 598-607.

Weiss SJ, Lampert MB, Test ST. (1983) Long-lived oxidants generated by human neutrophils. Characterisation and bioactivity. Science.; 227: 625-8. 